GEOUSP - Espaço e Tempo, São Paulo, № 16, pp. 163 - 164, 2004

\title{
NOTAS SOBRE O SEMINÁRI O SÃO PAULO 450 ANOS: AS “GEOGRAFIAS" DA METRÓPOLE
}

\author{
Camila Salles de Faria, Rafael Faleiros de Padua e Sávio Augusto de Freitas Miele*
}

A cidade de São Paulo, que neste ano completou 450 anos, foi objeto de amplas reflexões e discussões no Departamento de Geografia da Faculdade de Filosofia, Letras e Ciências Humanas da Universidade de São Paulo, com a realização do Seminário São Paulo 450 anos: As "Geografias" da Metrópole, ocorrido no período de 20 a 24 de setembro de 2004.

Vários temas relacionados a cidade e ao urbano, especificamente sobre à metrópole paulistana, foram tratados a partir das pesquisas realizadas pelos docentes do Departamento e professores convidados de universidades brasileiras e estrangeiras.

O Seminário foi constituído por mesasredondas e sessões de comunicação que abordaram questões sobre a cidade de São Paulo através da análise espacial, com o intuito de revelar os conteúdos dos processos de urbanização no mundo moderno.

A metrópole foi amplamente debatida enquanto noção, podendo ser um tipo específico de habitat, o ápice da hierarquia urbana, uma escala de análise para os diversos campos da Geografia e a expressão da espacialidade moderna do capitalismo totalmente consolidado. As metrópoles passaram ao longo dos anos por transformações, tendo uma grande extensão territorial e assumindo um papel de hegemonia cada vez maior, como também a inserção e a construção de uma complexa rede hierarquizada de cidades, o que aponta para o conceito de metropolização. Não se pode pensar a metrópole em si, senão como cidaderegião. A metrópole também não pode ser vista como homogênea, destacando-se aqui a periferia "plástica" e o entorno rural. A periferia plástica aparece como o lugar de expropriação e exploração da massa de trabalhadores e o lugar de uma nova pobreza: os desempregados permanentes. Caberia à faixa que corresponde ao entorno rural, que foi se estreitando ao longo dos anos, o abastecimento da cidade.

Mas a relação com a metrópole não é apenas regional, é também global. Daí apontouse diferenças conceituais entre cidade global, cidade mundial e cidade região-global. Para isso torna-se imprescindível destacar os fluxos internacionais tanto de migrantes, com diversas origens, resultando numa multiculturalidade, como de mercadorias, caracterizando uma economia complexa e sofisticada. Pois, no contexto da mundialização e da constituição da sociedade urbana, São Paulo aparece como a cidade dos negócios, revelando um movimento de passagem do capital industrial para o capital financeiro, que no plano espacial da metrópole se dá de forma fragmentada num determinado momento e lugar. Portanto, a reprodução do 
espaço urbano hoje na metrópole de São Paulo revela um momento em que a produção do espaço torna-se condição para a reprodução do capital financeiro. Neste sentido, tem-se a idéia de que o espaço está voltado ao consumo, desde os problemas habitacionais, pois a moradia só se realiza através da mediação do dinheiro, até o turismo, ressaltando o papel de São Paulo enquanto centro emissor de turistas frente ao turismo religioso, rural e ecoturismo como também atrativo para o turismo de negócios e de eventos.

É neste contexto que é necessário destacar o constante processo de transformação da cidade numa articulação entre o Estado e o capital privado, a desconcetração industrial, a deterioração de alguns bairros e a centralização do capital na metrópole e o setor financeiro e de serviços que buscam a centralidade.

A relação entre a urbanização acelerada de São Paulo e o meio natural radicalmente transformado por ela também foi objeto de discussões. Os debates em torno do clima urbano apontaram os fenômenos da ilha de calor, desconforto térmico, maior torrencialidade das chuvas, caracterização dos meses secos. Se coloca como fundamental pensar um método que relacione clima e cidade, preocupado com atividades urbanas e procurando também entender os processos atmosféricos com todas suas inter-relações.

É importante ressaltar a relação entre a urbanização e os efeitos nos sistemas geomorfológicos originais. Os desequilíbrios produzidos com a intensa urbanização, como por exemplo, o lixo e suas implicações quanto a sua alocação, a contaminação de águas superficiais e profundas, como também o abastecimento desta para a população.

Algumas mesas-redondas trouxeram a contribuição dos professores estrangeiros, tanto no sentido de pensar o olhar estrangeiro sobre São Paulo, como no sentido de pensar a universalidade da categoria metrópole.
Além destes temas rapidamente elencados aqui, muitos outros foram abordados no seminário, como a problemática indígena nos 450 anos da cidade, a Educação e a Cidade, técnicas de geo-referenciamento, enfim, temas que procuravam pensar a cidade através dos vários aspectos que a constituem.

Estes debates realizados no Seminário foram momentos privilegiados de reflexão sobre a metrópole de São Paulo a partir das mais variadas vertentes teórico-metodológicas e dos vários campos da Geografia. O processo de urbanização brasileiro se intensifica a partir da década de 50 do século XX e São Paulo vai gradativamente se colocando como a principal metrópole do país e hoje sua centralidade no contexto brasileiro é indiscutível. De modo que pensar esta metrópole brasileira, sul-americana e com aspectos de cidade mundial, ajuda-nos a entender as contradições presentes na sociedade brasileira. Assim, as discussões propostas pelo Seminário mostram sua pertinência no momento atual, quando inúmeras questões da sociedade brasileira ganham visibilidade através da metrópole.

Com o intuito de expandir o debate em torno da metrópole, foram lançados durante o Seminário dois livros da obra "As Geografias da Metrópole", livro 1 "Representação e Crise da Metrópole", livro 2 "Metrópole do Século XXI", que trazem os textos apresentados e proximamente será publicado o livro 3, com os demais trabalhos apresentados e que não estão nos dois primeiros livros. Esta obra é um esforço dos Geógrafos de apresentar à sociedade uma reflexão profunda sobre a maior metrópole brasileira. Esforço este iniciado na década de 1950 com a publicação da obra "A Cidade de São Paulo", coordenada por Aroldo de Azevedo, e que fazia parte das comemorações do IV Centenário. Hoje a cidade traz novos desafios para os pesquisadores, e tanto o Seminário como a obra agora lançada procuram avançar neste sentido. 